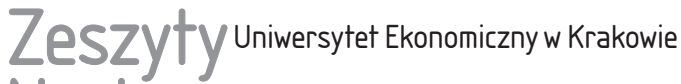 Naukowe
}

\section{Poczucie szacunku pracowników jako predyktor zaangażowania organizacyjnego*}

\section{Streszczenie}

Zarządzanie kapitałem ludzkim obecnie nie ogranicza się do motywowania pracowników w celu wykonywania przez nich powierzonych zadań. Firmy dążą do budowania kapitału złożonego z pracowników także zaangażowanych w organizację. Wysoki poziom zaangażowania niesie wiele korzyści dla organizacji, dlatego choć problematyka znana jest od lat, wciąż stanowi źródło zainteresowań naukowych i biznesowych. Pracownicy zaangażowani są lojalni wobec firmy, podejmują z własnej inicjatywy działania, dzięki którym przyczyniają się do poprawy efektywności organizacji.

W artykule zwrócono uwagę na potrzebę odczuwania szacunku w relacjach pracownika z przełożonym i jego znaczenia dla zaangażowania afektywnego, normatywnego i trwania.

Słowa kluczowe: zaangażowanie organizacyjne, doświadczanie szacunku, relacje z przełożonym, uznanie pracownika.

Klasyfikacja JEL: A1, A19.

Alicja Szczygieł, Uniwersytet Ekonomiczny w Krakowie, Wydział Ekonomii i Stosunków Międzynarodowych, Katedra Psychologii i Dydaktyki, ul. Rakowicka 27, 31-510 Kraków, e-mail: szczygia@uek.krakow.pl

* Artykuł jest wynikiem realizacji badań sfinansowanych ze środków przyznanych Wydziałowi Ekonomii i Stosunków Międzynarodowych Uniwersytetu Ekonomicznego w Krakowie na utrzymanie potencjału badawczego. 


\section{Wprowadzenie}

Firmy dążą obecnie do budowania kapitału złożonego z pracowników nie tylko zmotywowanych, ale także zaangażowanych $w$ organizację. Wysoki poziom zaangażowania niesie wiele korzyści dla organizacji, takich jak: lojalność wobec firmy, podejmowanie z własnej inicjatywy działań, wykraczanie poza zakres swoich obowiązków, dzięki temu przyczyniając się do poprawy efektywności organizacji (Łaguna i in. 2015, s. 278). Dla każdej organizacji korzystne jest więc wspieranie aktywnych i sumiennych pracowników i zarządzanie nimi w taki sposób, aby postawy takie umacniać.

W niniejszym artykule zwrócono szczególną uwagę na potrzebę odczuwania szacunku przez pracowników ze strony kierownika. Podjęto próbę odpowiedzi na pytanie, czy doświadczanie szacunku w relacjach z przełożonym ma znaczenie dla zaangażowania organizacyjnego pracownika. W tym celu wykorzystano wyniki badań, które zostały przeprowadzone przez zespół pracowników Katedry Psychologii i Dydaktyki Uniwersytetu Ekonomicznego w Krakowie. Zakres zainteresowań naukowo-empirycznych obejmował problematykę psychospołecznych aspektów zaangażowania organizacyjnego. Projekt zrealizowano w ramach tematu badawczego nr 064/WE-KPD/02/2014/S/4260.

\section{Zaangażowanie organizacyjne a poczucie szacunku}

Pojęcie zaangażowania jest wielowymiarowe i odnosi się do różnych aspektów związanych z zachowaniem podmiotu. R. Mowday uważa, że zaangażowanie złożone jest z trzech elementów: 1) identyfikacji z celami i wartościami organizacji, 2) pragnienia przynależności do organizacji, 3) chęci zdobycia się na wysiłek na rzecz organizacji (Amstrong 2001, s. 126). Zdaniem L.M. Ericssona „Zaangażowanie jest czymś więcej niż satysfakcją z warunków stworzonych przez pracodawcę lub prostą lojalnością wobec niego (...). Zaangażowanie jest raczej związane z pasją i poświęceniem - chęcią danej osoby do zainwestowania i włożenia własnego wysiłku w sukces pracodawcy" (Juchnowicz 2012, s. 34). Zgodnie z koncepcją W.A. Kahna zaangażowanie „to stan psychiczny, który umożliwia pracownikom wyrażanie siebie podczas wykonywanej pracy" (Adamska-Chudzińska 2015, s. 48).

Według W.A. Kahna działanie pracownika może zachodzić w wymiarze poznawczym, fizycznym i emocjonalnym. C.E.J. Härtel rozwinął koncepcję W.A. Kahna o „poświęcenie jednostki, satysfakcję i entuzjazm do pracy” (Rudawska 2011, s. 77). W.B. Schaufeli i współpracownicy (Juchnowicz 2012, s. 36) definiują zaangażowanie jako pozytywny stan związany z pracą. Nie jest 
on przejściowy, ale trwały (Saks 2006). Zdaniem M. Juchnowicz postawa zaangażowania przejawia się w zaangażowaniu poznawczym, emocjonalnym, fizycznym i identyfikacyjnym. Osoba zaangażowana w wysokim stopniu koncentruje się na zadaniu, pracę wykonuje $\mathrm{z}$ zadowoleniem i pasją, podejmuje różne działania $\mathrm{w}$ organizacji, w tym związane $\mathrm{z}$ rozwojem, a także jest pozytywnie nastawiona do miejsca swojego zatrudnienia (Juchnowicz 2012, s. 36).

Model J.P. Meyera i N.J. Allen zakłada, że ,przywiązanie organizacyjne to siła identyfikacji oraz przywiązania do określnej organizacji i pozostawania w jej ramach" (Chrupała-Pniak i Grabowski 2014, s. 85). Tak rozumiane zaangażowanie składa się z trzech komponentów: afektywnego, normatywnego i emocjonalnego (Meyer, Allen i Smith 1993).

Zaangażowanie afektywne oparte jest na emocjonalnym poczuciu wspólnoty, jakie pracownik odczuwa z firmą, w której pracuje. Najczęściej są to emocje pozytywne wynikające m.in. $z$ dobrych relacji interpersonalnych i doświadczeń Pracownicy z silnym zaangażowaniem afektywnym pozostają w pracy, odczuwają przyjemność bycia członkiem organizacji (Bergman 2006). Na ten rodzaj zaangażowania mają wpływ m.in. doświadczenia zawodowe, poczucie bycia sprawiedliwie traktowanym przez przełożonego, poczucie komfortu i kompetencji, cechy osobowości, cechy organizacji.

Zaangażowanie normatywne wynika z postawy spostrzegania zobowiązań wobec organizacji. Pracownik odczuwa potrzebę pozostania w organizacji i bycia lojalnym wobec miejsca pracy. Kształtowanie się takiego zaangażowania zależy od inwestowania w pracownika, norm wzajemności oraz systemu wartości organizacji.

Pracownicy z silnym zaangażowaniem trwania pozostają w firmie, ponieważ są świadomi kosztów zarówno gospodarczych, jak i społecznych, jakie poniosą, gdy zdecydują się na opuszczenie organizacji (Jaros 2007). Zaangażowanie trwania rozwija m.in. kultura organizacyjna i alternatywy innego zatrudnienia.

Zaangażowanie afektywne w porównaniu z innymi wpływa na dobre relacje w pracy, podejmowanie samodzielnych działań, motywację do rozwoju, a w największym stopniu zwiększanie efektywności pracy (Kmiotek 2016, s. 84). W organizacji może być ono kształtowane przez wiele obszarów.

W literaturze przedmiotu (Meyer, Allen i Smith 1993, Amstrong 2001, Erben i Güneşer 2007, Juchnowicz 2012, Kmiotek 2016) przedstawianych jest wiele czynników, które przyczyniają się do zaangażowania pracownika, wśród nich wymienia się znaczenie bycia docenionym. Poczucie zaspokojenia tej potrzeby jest bliskie każdemu człowiekowi, gdyż należy ona do „repertuaru podstawowych i ustalonych elementów natury ludzkiej” (Maslow 2013, s. 115). Pracownikom zależy na byciu zauważonym i docenionym przez swoich przełożonych i organizację, jednak nie zawsze ma to miejsce, wielu z nich odczuwa brak szacunku i należytej uwagi. Ch. Porath na podstawie przeprowadzonych badań dwudziestu tysięcy osób 
z różnych branż i organizacji stwierdziła, że „najważniejszą rzeczą, jakiej ludzie oczekują od swoich liderów, jest szacunek. Szacunek wyprzedził uznanie i wdzięczność, przekazywanie inspirującej wizji, udzielanie przydatnych informacji zwrotnych, a nawet możliwości zdobywania wiedzy, rozwoju i doskonalenia umiejętności" (Porath 2013).

Istotną rolę odgrywa zachowanie bezpośredniego przełożonego, który ma wpływ na sposób funkcjonowania i spostrzegania organizacji przez pracownika. Wśród dziesięciu najważniejszych warunków efektywnego zaangażowania wymienia się relacje z bezpośrednim przełożonym i dobrą komunikację wewnętrzną (Juchnowicz 2012, s. 53). C. Maslach sugeruje, że odpowiednie uznanie i nagroda są ważne dla zaangażowania, a ich brak może prowadzić do wypalenia (Saks 2006). Odpowiednio wyrażone uznanie i docenienie pracowników wpływa na zaspokajanie u nich jednych z najważniejszych potrzeb. Ludzie odczuwają potrzebę szacunku, pragnienie wysokiej oceny i poważania ze strony innych. Zaspokojenie potrzeby szacunku prowadzi do „poczucia pewności siebie, własnej wartości, kompetencji, (...) poczucia, że jest się pożytecznym i potrzebnym w świecie. Udaremnienie zaspokojenia tych potrzeb wywołuje poczucie niższości, słabości i bezradności, które prowadzą do ogólnego zniechęcenia" (Maslow 2013, s. 70).

Bilans korzyści dla organizacji i kosztów poniesionych z powodu uznania i poszanowania pracownika przez przełożonego są nieporównywalne. Wśród pozytywnych aspektów wymienia się zadowolenie z pracy i chęć przebywania w niej, mniejszą absencję, dobrą pracę zespołową, satysfakcję klientów firmy oraz zadowalającą jakość wykonywanych obowiązków. Pracownik zauważony i doceniony zwiększa wydajność podjętych przez siebie działań. Pozytywne wzmocnienie pożądanego zachowania wpływa na chęć ponownego powtórzenia go. W porównaniu z korzyściami, jakie zyskuje organizacja, poniesione koszty są niewielkie (Harrison 2013). Przede wszystkim należy poświęć czas i uwagę pracownikowi. Traktować go w sposób podmiotowy, a nie (jak ma to czasami miejsce) w sposób przedmiotowy.

Niejednokrotnie kontakt z przełożonym ogranicza się do e-maili, autorytatywnego zlecania i wyznaczania obowiązków. Brakuje zauważenia pozytywnych efektów pracy, rozmów, wymiany poglądów, zainteresowania się pracownikiem jako człowiekiem, a nie tylko wykonawcą. Postawę i zachowanie przełożonych potwierdzają wyniki badań uzyskane przez E. Bombiak (2010, s. 88). Analizując ranking czynników, które wpływają na zaangażowanie, w opinii pracowników i ich przełożonych zauważyć można pewną różnicę. Wśród najważniejszych dwudziestu czterech analizowanych aspektów wyrazy uznania i szacunku zostały wybrane na dziesiątym miejscu przez pracowników i na osiemnastym miejscu przez ich przełożonych (tabela 1). 
Tabela 1. Ranking czynników mających wpływ na zaangażowanie w opinii pracowników i przełożonych

\begin{tabular}{|c|c|}
\hline Ocena podwładnych & Ocena przełożonych \\
\hline Wynagrodzenie zasadnicze & Wynagrodzenie zasadnicze \\
\hline Bonusy & Bonusy \\
\hline Udział w zysku & Udział w zysku \\
\hline Możliwość rozwoju & Premie \\
\hline Dobre stosunki międzyludzkie & Możliwość rozwoju \\
\hline Premie & Nagrody pieniężne \\
\hline Oceny okresowe & Odpowiednie warunki pracy \\
\hline Awans & Dobre stosunki międzyludzkie \\
\hline Samodzielność w podejmowaniu decyzji & Oceny okresowe \\
\hline Wyrazy uznania i szacunku & Poczucie bezpieczeństwa zatrudnienia \\
\hline Odpowiednie warunki pracy & Perswazja racjonalna \\
\hline Perswazja racjonalna & Awans \\
\hline Nagrody pieniężne & Samodzielność w podejmowaniu decyzji \\
\hline Atrakcyjna treść pracy & Duma z pracy w firmie \\
\hline Partycypacja decyzyjna w zarządzaniu & Nagrody rzeczowe \\
\hline Duma z pracy w firmie & Atrakcyjna treść pracy \\
\hline Poczucie bezpieczeństwa zatrudnienia & Partycypacja decyzyjna w zarządzaniu \\
\hline Wyróżnienia & Wyrazy uznania i szacunku \\
\hline Dogodne formy organizacji pracy & Wyróżnienia \\
\hline Nagrody rzeczowe & Elastyczny czas pracy \\
\hline Elastyczny czas pracy & Dogodne formy organizacji pracy \\
\hline Świadczenia socjalne & Świadczenia socjalne \\
\hline Perswazja emocjonalna & Perswazja emocjonalna \\
\hline $\begin{array}{l}\text { Nakazy, zakazy, polecenia, regulaminy, normy } \\
\text { i instrukcje pracy }\end{array}$ & $\begin{array}{l}\text { Nakazy, zakazy, polecenia, regulaminy } \\
\text { normy i instrukcje pracy }\end{array}$ \\
\hline
\end{tabular}

Źródło: (Bombiak 2010, s. 68).

Zaangażowanie pracowników w organizacji związane jest z możliwością zaspokajania przez nich indywidulanych potrzeb. Wynagrodzenie zasadnicze sprzyja zaspokajaniu podstawowych potrzeb (zgodnie z teorią Maslowa), ale dla zatrudnionych osób mają także duże znacznie potrzeby wyższego rzędu, które dotyczą możliwości własnego rozwoju, relacji ze współpracownikami czy poważania w pracy. Ludzie nie tylko zwracają uwagę na materialny wymiar pracy, ale chcą, aby inne osoby zauważały ich wysiłek oraz darzyły szacunkiem. 


\section{Poczucie szacunku pracownika w świetle badań}

Badanie odczuwania szacunku przeprowadzono w ramach rozbudowanego kwestionariusza „Zaangażowanie w organizacji”, którego celem było ustalenie czynników wpływających na zaangażowanie pracowników, opracowanego w ramach wymienionego projektu.

Celem badań było wykazanie znaczenia doświadczania szacunku przez pracowników w relacjach z przełożonymi dla ich zaangażowania organizacyjnego. Założono, że szanowanie pracownika oparte na dobrej komunikacji, wsparciu i możliwościach rozwoju ma znaczenie dla jego zaangażowania.

Prezentowane wyniki badań dotyczą głównie obszaru związanego z relacjami pomiędzy przełożonym a pracownikiem $\mathrm{w}$ wybranych aspektach poprawnego komunikowania oraz rodzajem zaangażowania podwładnych. Postawiono następujące pytania badawcze:

- czy istnieje związek między odczuwaniem szacunku przez pracownika w relacjach z przełożonym a zaangażowaniem?

- czy uznanie przełożonego wobec pracownika wyrażone w komunikacie werbalnym ma znaczenie dla jego zaangażowania?

Zaspokojenie potrzeby szacunku badano autorską skalą zbudowaną z dziewięciu stwierdzeń, które zostały poddane analizie rzetelności metodą Alfa Cronbacha (tabela 2). Wskaźnik rzetelności wyniósł 0,8 (przyjmuje się, że wartości powyżej 0,7 oznaczają prawidłową rzetelność skali), co świadczy o wysokiej zgodności zawartych w niej stwierdzeń. Zdania w kwestionariuszu służyły ustalaniu odczuwania szacunku przez pracownika, który dotyczył trzech głównych aspektów: relacji z przełożonym opartej na docenianiu pracownika w postaci słownego komunikatu, stwarzaniu możliwości rozwoju pracownikowi oraz udzielania mu wsparcia.

Do badania zaangażowania organizacyjnego wykorzystano kwestionariusz J.P. Mayer, N.J. Allen (Bańka, Wołoska i Bazińska 2002, Meyer i Allen 1991, Meyer, Allen i Smith 1993). Narzędzie odnosi się do opisywanej wyżej koncepcji i sprawdza zaangażowanie afektywne, normatywne i trwania. Kwestionariusz składa się z 18 stwierdzeń, po sześć dla każdego rodzaju zaangażowania.

$\mathrm{W}$ opisywanych obydwu narzędziach badawczych wykorzystano 5 -stopniową skalę Likerta, w której zastosowano następujące odpowiedzi: „zdecydowanie się nie zgadzam” do „zdecydowanie się zgadzam” (w tym jedno twierdzenie: „trudno powiedzieć”). Uzyskane wyniki analizowano z wykorzystaniem współczynnika korelacji liniowej Pearsona $(p<0,05)$ oraz tau-Kendalla $(p<0,05)$.

W badaniu wzięło udział 535 osób, w tym 81,26\% stanowiły kobiety, a 21,03\% mężczyźni. Grupa badawcza składała się z studentów studiów zaocznych i pody- 
plomowych Uniwersytetu Ekonomicznego w Krakowie, którzy byli osobami pracującymi.

Tabela 2. Kwestionariusz dotyczący odczuwania szacunku

\begin{tabular}{|c|}
\hline Wyszczególnienie \\
\hline 1. Przełożony chwali moją pracę (mnie) w obecności innych \\
\hline 2. Przełożony dziękuje mi za zrealizowane zadanie (projekt) \\
\hline 3. Przełożony angażuje mnie do udziału w ważnych projektach firnowych \\
\hline 4. Przełożony inwestuje w mój rozwój zawodowy \\
\hline 5. Przełożony zauważa moje zaangażowanie w pracę, mówiąc o tym w rozmowie bezpośredniej \\
\hline 6. Przełożony szanuje moje zdanie, wysłuchując argumentów \\
\hline 7. Przełożony znajduje dla mnie czas, gdy go o to proszę \\
\hline $\begin{array}{l}\text { 8. Mogę liczyć na pomoc i wsparcie przełożonego w rozwiązywaniu problemów } \\
\text { zawodowych }\end{array}$ \\
\hline $\begin{array}{l}\text { 9. Mogę liczyć na pomoc i wsparcie przełożonego w rozwiązywaniu moich prywatnych } \\
\text { problemów }\end{array}$ \\
\hline
\end{tabular}

Źródło: opracowanie własne.

Problematyka opisywanych w niniejszym artykule badań dotyczyła relacji pracowników z ich przełożonymi, dlatego eksploracji poddano wyniki uzyskane z wyłączeniem osób zajmujących stanowiska kierownicze oraz właścicieli firm. Na tej podstawie otrzymano grupę liczącą 446 respondentów, którzy współpracowali ze swoimi przełożonymi, w tym 81,17\% stanowiły kobiety, a 18,83\% mężczyźni. Badani byli zatrudnieni w firmach różnych pod względem wielkości i sektora gospodarki. Ponad połowa pracowała w mikro- i małych firmach (odpowiednio $32,72 \%$ i $28,21 \%$ ), 22,06\% w przedsiębiorstwach średnich, pozostali badani byli zatrudnieni w firmach powyżej 250 pracowników (22,06\%). Część osób deklarowała poniżej 6-miesięczny staż pracy $(23,31 \%)$, podobna liczba osób zatrudniona była w firmie od roku (28,25\%). Największą liczbę stanowili respondenci pracujący od roku do 5 lat $(40,13 \%)$, a najmniejszą osoby pracujące odpowiednio od 5 do 10 lat i więcej $(4,48 \%$ i $3,13 \%)$.

\section{Wyniki badań}

Otrzymane wyniki potwierdzają, że doświadczanie szacunku przez pracownika ma znaczenie dla jego zaangażowania. Na podstawie uzyskanych odpowiedzi stwierdzono zależność istotną statystycznie z zaangażowaniem afektywnym $(0,48)$ i zaangażowaniem normatywnym $(0,50)$. Nie stwierdzono zależności z zaangażowaniem trwania. Odczuwanie szacunku w pracy jest ważne dla kobiet i dla mężczyzn. 
W badanej grupie stwierdzono wzrost zaangażowania afektywnego i normatywnego (odpowiednio kobiety 0,45 i mężczyźni 0,60 oraz kobiety 0,50 i mężczyźni 0,53 ), który był uwarunkowany m.in. dobrymi relacjami z przełożonym.

Wielkość firmy, w której zatrudnione były osoby, ma znaczenie dla ich zaangażowania. Analiza wyników wykazała istotną zależność dla zaangażowania trwania $(-0,17)$ i zaangażowania normatywnego $(-0,11)$. Im większa firma, tym mniejsze zaangażowanie pracowników w analizowanych aspektach, natomiast wielkość firmy nie ma związku z zaangażowaniem afektywnym w badanej grupie. Staż pracy respondentów nie miał znaczenia dla ich zaangażowania normatywnego, trwania i afektywnego.

Biorąc pod uwagę zależność pomiędzy pochwałą przełożonego w obecności innych osób a zaangażowaniem, otrzymano wynik istotny statystycznie dla zaangażowania afektywnego $(0,30)$ i normatywnego $(0,31)$. Nie stwierdzono związku $\mathrm{z}$ zaangażowaniem trwania.

Badani pracownicy nie są zbyt często doceniani przez przełożonego w obecności innych osób. Niewiele więcej niż połowa respondentów $(51,0 \%)$ stwierdziła, że doświadcza pochwały w takich sytuacjach, w tym 14,31\% udzieliło odpowiedzi „zdecydowanie tak”. 49,0\% osób nie było doceniane przy innych pracownikach (17,71\% udzieliło odpowiedzi „raczej nie”, 3,99\% „zdecydowanie nie”, pozostałym trudno było wyrazić zdanie $27,31 \%$ ).

Nie stwierdzono zależności istotnej statystycznie pomiędzy stażem przepracowanym w firmie a stosowaniem pochwał przez przełożonych. Liczba osób zatrudnionych w firmie nie miała związku statystycznego z zachowaniem przełożonych i udzielaniem przez nich otwartych pochwał swoim podwładnym. Niewiele ponad połowa badanych osób bez względu na miejsce zatrudnienia była nagradzana w opisywany sposób (rys. 1).

Na podstawie uzyskanych wyników stwierdzono istotną zależność między podziękowaniem przez przełożonego pracownikowi za zrealizowane przez niego zadanie a zaangażowaniem afektywnym $(0,36)$ i normatywnym $(0,37)$.

Menedżerowie rzadko dziękują swoim pracownikom za zrealizowane zadanie. Pozytywnych odpowiedzi dzieliło 58,91\% osób, w tym 19,7\% „zdecydowanie tak”. Nie słyszy podziękowania $21,95 \%$ osób (15,38\% odpowiedziało „raczej nie” i 6,57\% „zdecydowanie nie”). Reszta osób nie miała zdania na ten temat.

Pracownicy zatrudnieni w dużych firmach w 67,8\% informowali, że przełożeni dziękują im za zrealizowane zadanie. Osoby zatrudnione w średnich firmach nie zetknęły się z taką postawą przełożonego w $58,24 \%$, podobna liczba pracowników z małych $(52,02 \%)$ i mikrofirm $(60 \%)$. Około $50 \%$ respondentów nie współpracuje z przełożonymi, którzy dziękowaliby im za zrealizowany projekt lub zadanie (rys. 2). 


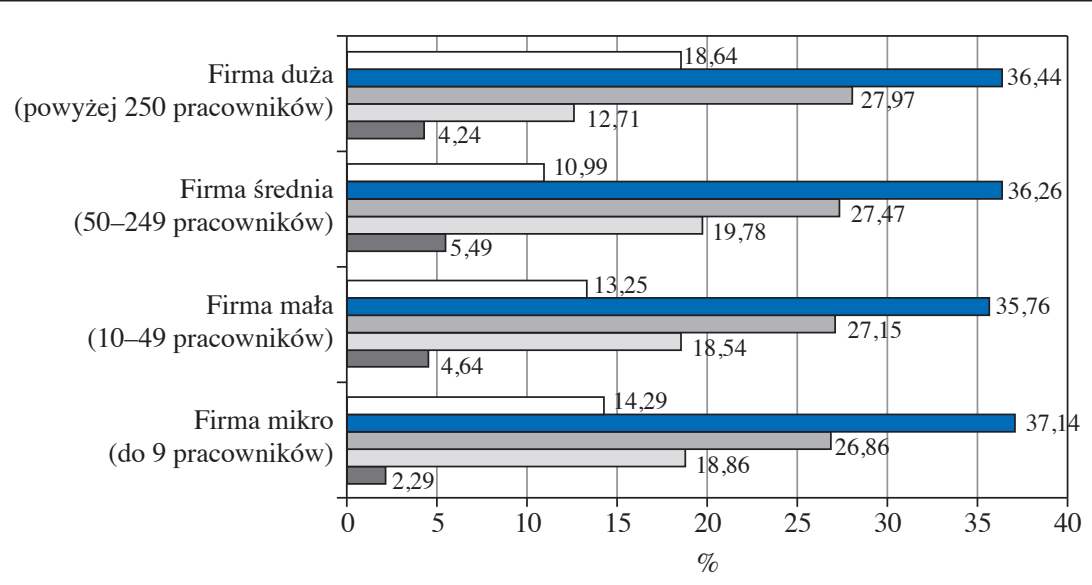

$\square$ zdecydowanie tak $\square$ raczej nie

$\square$ raczej tak $\square$ trudno powiedzieć $\square$ zdecydowanie nie

Rys. 1. Pochwała pracownika przez przełożonego w obecności innych osób Źródło: opracowanie własne.

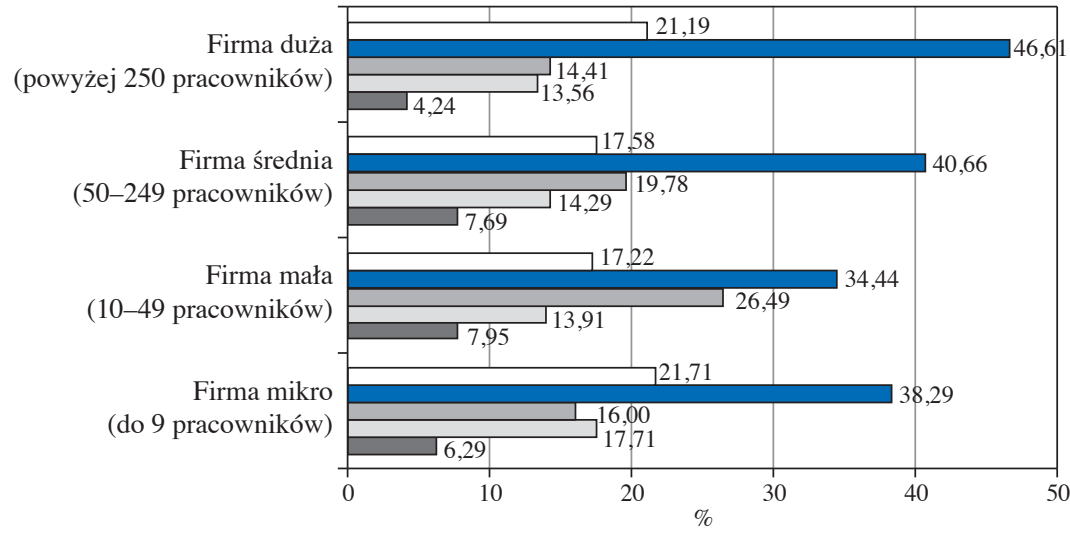

$\square$ zdecydowanie tak raczej tak $\square$ trudno powiedzieć $\square$ raczej nie $\square$ zdecydowanie nie

Rys. 2. Podziękowanie pracownikowi za zrealizowane zadanie (projekt)

Źródło: opracowanie własne. 
Nie stwierdzono związku istotnego statystycznie pomiędzy wielkością firmy a stosowaniem pozytywnego komunikatu przez przełożonych, także czas zatrudnienia nie ma związku z omawianym sposobem komunikowania w badanej grupie.

Na podstawie uzyskanych wyników stwierdzono istotny związek między zauważaniem przez przełożonego zaangażowania $\mathrm{w}$ pracę i informowania o tym pracownika w rozmowie bezpośredniej a zaangażowaniem afektywnym $(0,31)$ oraz normatywnym $(0,33)$. Nie stwierdzono związku z zaangażowaniem trwania.

Niewiele ponad połowa badanych uważała, że przełożony informuje ich o swoich pozytywnych spostrzeżeniach dotyczących zaangażowania w pracę (18,16\% przyznało odpowiedzi zdecydowanie tak i 42,70\% „raczej tak”), część osób, czyli 20,04\%, udzieliło negatywnej odpowiedzi (w tym 5,06\% „zdecydowanie nie"), 19,10\% miało trudności w wyrażeniu opinii na ten temat.

Wielkość firmy i staż pracy podwładnych nie wpływa na zachowania przełożonych charakteryzujących się docenieniem w rozmowie bezpośredniej zaangażowania pracownika (rys. 3). Nie zaobserwowano także związku statystycznego w tych aspektach.

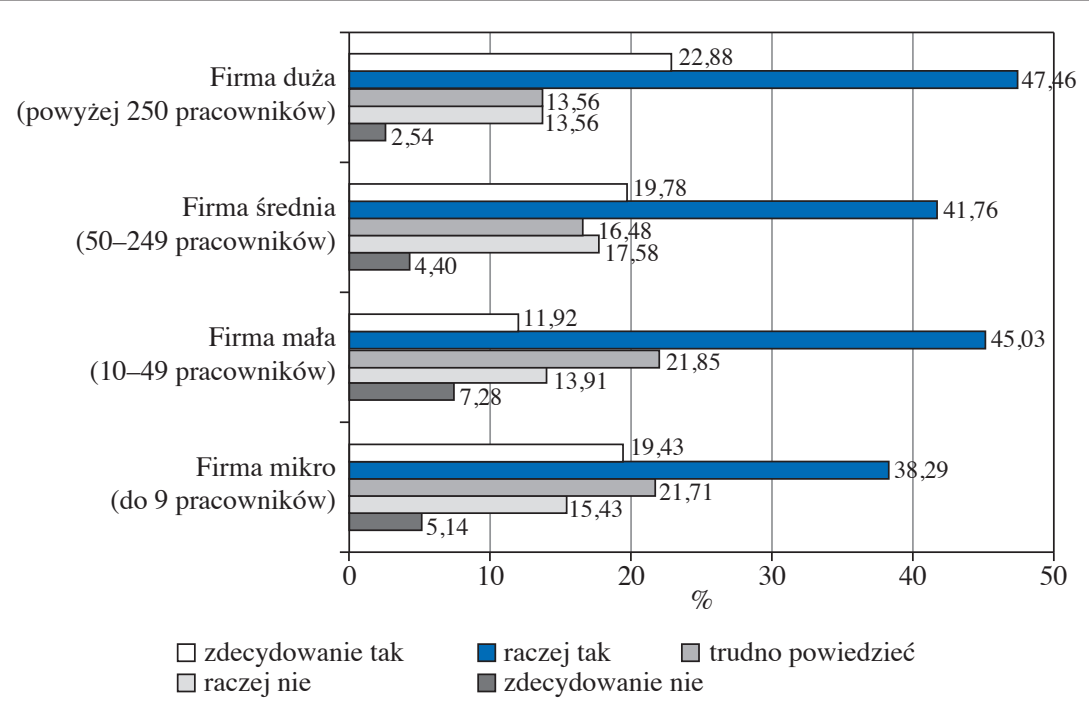

Rys. 3. Zauważenie przez przełożonego w rozmowie bezpośredniej zaangażowania pracownika

Źródło: opracowanie własne.

Badania wykazały, że słuchanie argumentów pracownika i szanowanie jego zdania ma znacznie dla jego zaangażowania afektywnego $(0,32)$ oraz normatywnego $(0,32)$. 
Grupa $66,60 \%$ badanych stwierdziła, że kierownicy wykazują motywację do wysłuchania ich zdania i szanują je (20,88\% „raczej tak”, 47,84\% „zdecydowanie tak”), część osób (12,57\%, w tym: 2,81\% „zdecydowanie nie” i 9,76 „raczej nie”) zadeklarowała, że takie zachowanie przełożonego nie ma miejsca, pozostali respondenci, tj. 20,83\%, nie mieli zdania na ten temat.

Wielkość firmy nie ma wpływu na relacje pracowników z przełożonymi w zakresie aktywnego słuchania (rys. 4).

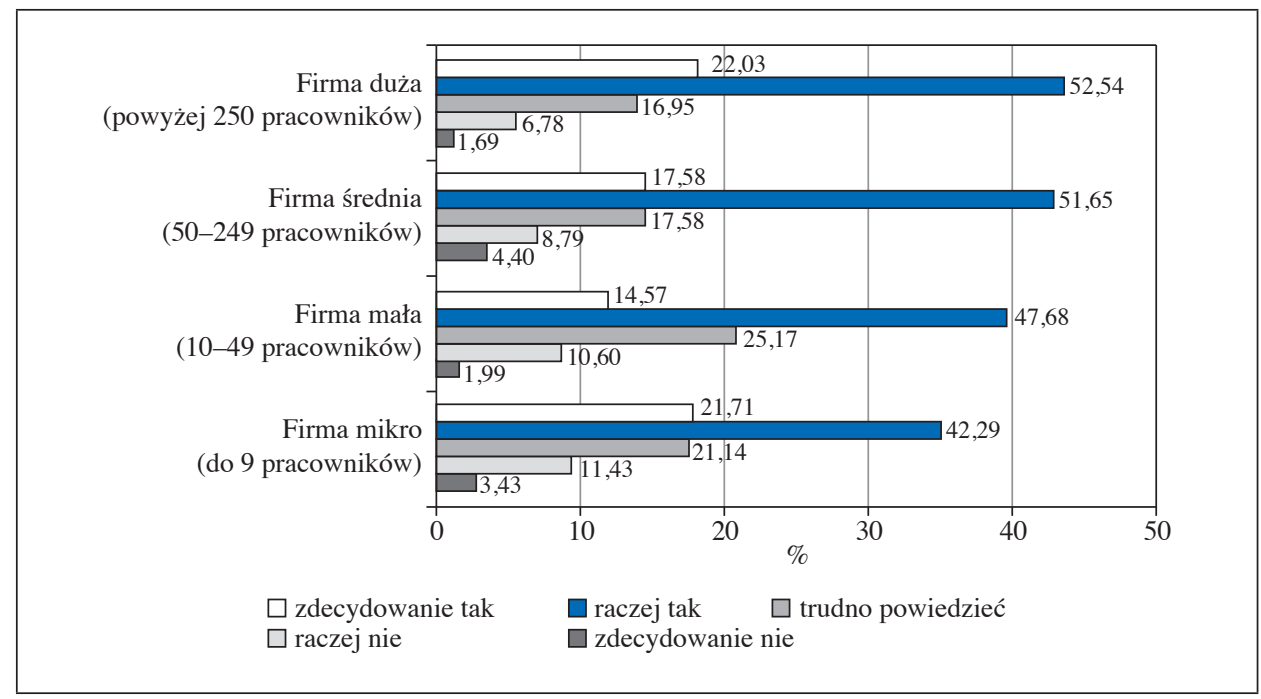

Rys. 4. Przełożony szanuje zdanie i wysłuchuje argumentów pracowników Źródło: opracowanie własne.

Nie stwierdzono także istotnego związku pomiędzy wysłuchaniem opinii pracownika przez przełożonego a wielkością firmy. Sposób prowadzenia rozmowy przez przełożonego i szanowanie zdania pracownika mają związek ze stażem pracy $(0,06)$, ale jest to korelacja o nikłej sile.

\section{Zakończenie}

Odczuwanie szacunku przez pracownika w relacji z bezpośrednim przełożonym ma znaczenie dla jego zaangażowania afektywnego i normatywnego, natomiast nie wpływa na zaangażowanie trwania. Bez względu na płeć pracownicy cenią sobie pozytywne relacje z przełożonym. Postępowanie zwierzchnika wpływa na ich pozytywne nastawienie wobec organizacji i chęć wypełnienia 
swoich obowiązków. Należy jednak nadmienić, że w badanej grupie było zdecydowanie więcej kobiet. Dlatego ta problematyka wymaga jeszcze pogłębionych badań naukowych.

Staż pracy respondentów nie wpływał na ich zaangażowanie organizacyjne. W odróżnieniu od ilości przepracowanego czasu, wielkość firmy miała znaczenie dla ich zaangażowania trwania i normatywnego. Im mniejsza firma, tym zaangażowanie było większe. Można przypuszczać, że osoby zatrudnione w mniejszym przedsiębiorstwie chętniej się z nim identyfikują i postrzegają jako miejsce dla siebie atrakcyjne. Pracownicy większej organizacji są mniej do niej przywiązani, rzadziej angażują się w sprawy zawodowe z poczuciem zobowiązania i lojalności. Zaangażowanie afektywne pracowników nie zależy od wielkości przedsiębiorstwa, w którym pracują. Liczba zatrudnionych pracowników w firmie nie przyczynia się do budowania pozytywnej postawy i emocjonalnego zaangażowania. Praca w dużej firmie może wpływać na poczucie choćby częściowej anonimowości podwładnych i rzadkich kontaktów z przełożonymi lub nawiązywaniu relacji wyłącznie służbowych. Działanie w takim środowisku nie generuje postawy oddanego pracownika.

Uzyskane wyniki potwierdziły istotną rolę postawy kadry zarządzającej wobec osób im podległych. Pracownicy cenią sobie rozmowę z przełożonym opartą na wzajemnym szacunku i zrozumieniu. Otrzymane wyniki potwierdziły, że jest to istotny czynnik wpływający na ich zaangażowanie afektywne i normatywne. Wiele firm nie docenia lub nie jest świadoma roli pozytywnego traktowania zatrudnionych osób. Pochwała jako forma nagrody ma moc sprawczą, która, gdy zostanie wyrażona w odpowiedni sposób, sprzyja zyskiwaniu lojalnego i aktywnego pracownika inicjującego działania na rzecz organizacji. Wydaje się jednak, że przełożeni zbyt rzadko w sposób werbalny wyrażają swoje uznanie. Otrzymane wyniki wykazały, że znaczna grupa badanych pracowników nie współpracuje z przełożonymi, którzy chwalą ich w rozmowie bezpośredniej lub w obecności innych. Tylko część osób prowadzi rozmowy, w których menedżer wysłuchuje i szanuje ich zdanie.

Wielkość firmy i liczba zatrudnionych w niej osób nie ma znaczenia dla postawy szacunku przełożonego wobec pracowników. Zarówno w firmach mikro, jak i makro przełożeni nie wyróżniali się swoim sposobem komunikowania, podczas którego wyrażaliby pozytywne zdanie na temat pracy podwładnych lub aktywnie słuchiwali ich opinii. Staż pracy respondentów także nie wpływał na zmianę zachowania i sposobu prowadzenia rozmów przez przełożonych. Odstępstwo dotyczy współpracy kierowników z pracownikami o długim okresie zatrudnienia. Postawa taka może wynikać z darzenia pracowników zaufaniem oraz wiedzy na temat kompetencji i ich doświadczenia. Liczba dni i lat spędzonych w miejscu pracy sprzyja lepszemu, wzajemnemu poznaniu. 
Deficyt rozmów z pracownikami, wyrażanie dobrego zdania i docenianie werbalne ich zaangażowania może wynikać $\mathrm{z}$ wielu przesłanek. Jedną z nich jest nieumiejętność prowadzenia rozmów z osobami odpowiedzialnymi za zarządzanie pracownikami. Nasuwa się wniosek o ciągłej potrzebie podnoszenia kwalifikacji z zakresu kompetencji miękkich pracowników, a w szczególności kadry zarządzającej.

W prowadzonych rozważaniach nad pochwałą pracownika należy pamiętać, że musi mieć ona uzasadnienie w działaniach, które były przez niego podejmowane. Uzyskane wyniki stanowią inspirację do podejmowania kolejnych rozważań $\mathrm{w}$ istotnym obszarze natury człowieka i zaspokajania ważnych dla niego potrzeb w organizacji.

\section{Literatura}

Adamska-Chudzińska M. (2015), Zaangażowanie organizacyjne pracowników jako źródło uczestnictwa w organizacji, ,Zeszyty Naukowe Uniwersytetu Ekonomicznego w Krakowie", nr 8(944), https://doi.org/10.15678/ZNUEK.2015.0944.0804.

Amstrong M. (2001), Zarzqdzanie zasobami ludzkimi, Dom Wydawniczy ABC, Warszawa.

Bańka A., Wołowska A., Bazińska R. (2002), Polska wersja Meyera i Allen Skali Przywiqzania do Organizacji, „Czasopismo Psychologiczne”, $\mathrm{nr} 8$.

Bergman M.E. (2006), The Relationship between Affective and Normative Commitment: Review and Research Agenda, ,Journal of Organizational Behavior”, vol. 27, nr 5, https://doi.org/10.1002/job.372.

Bombiak E. (2010), Motywowanie pracowników w świetle badań empirycznych, „Zeszyty Naukowe Akademii Podlaskiej w Siedlcach", Seria: Administracja i Zarządzanie, nr 86.

Chrupała-Pniak M., Grabowski D. (2014), Motywacyjne i organizacyjne predyktory zaangażowania pracowników, „Prace Naukowe Uniwersytetu Ekonomicznego we Wrocławiu", nr 350, https://doi.org/10.15611/pn.2014.350.07.

Erben G., Güneşer A. (2007), The Relationship between Paternalistic Leadership and Organizational Commitment: Investigating the Role of Climate Regarding Ethic, https://pdfs.semanticscholar.org/36e0/808787e512705e73e487749af98074dfc8d4.pdf (data dostępu: 15.05.2018).

Harrison K. (2013), Why Employee Recognition Is so Important. Cutting Edge-PR, http:// www.cuttingedgepr.com/articles/emprecog_so_important.asp (data dostępu: 5.03.2018).

Jaros S. (2007), Meyer and Allen Model of Organizational Commitment: Measurement Issues, „The Icfai Journal of Organizational Behavior”, vol. 6, $\mathrm{nr} 4$, http://stevejaros. com/wp-content/uploads/2009/08/Jaros-ICFAI-2007-Meyer-and-Allen1.pdf (data dostępu: 1.04.2018).

Juchnowicz M. (2012), Zaangażowanie pracowników, PWE, Warszawa.

Kmiotek K. (2016), Uwarunkowania zaangażowania organizacyjnego pracowników (przykład inżynierów), „Nauki o Zarządzaniu, Management Sciences”, nr 2(27). 
Łaguna M., Mielniczuk E., Żaliński A., Wałachowska K. (2015), Przywiqzanie do organizacji $i$ zaangażowanie $w$ prace - koncepcje teoretyczne i problemy terminologiczne, „Medycyna Pracy”, nr 66(2), https://doi.org/10.13075/mp.5893.00169.

Maslow A. (2013), Motywacja i osobowość, Wydawnictwo Naukowe PWN, Warszawa.

Meyer J.P., Allen N.J. (1991), A Threecomponent Conceptualization of Organizational Commitment, „Human Resource Management Review”, vol. 1, nr 1, https://doi. org/10.1016/1053-4822(91)90011-z.

Meyer J.P., Allen N.J., Smith C.A. (1993), Commitment to Organizations and Occupations: Extension and Test of a Tree-Component Conceptualization, „Journals of Appleid Psychology", vol. 78, nr 4, https://doi.org/10.1037//0021-9010.78.4.538.

Porath Ch. (2013), Jak odnosić sukcesy w pracy, gdy twój szef cię nie szanuje? „Harvard Business Review", http://www.hbrp.pl/b/jak-odnosic-sukcesy-w-pracy-gdy-twoj-szef-cie-nie-szanuje/6uPEX19j (data dostępu: 4.04.2018).

Rudawska A. (2011), Motywowanie do zaangażowania w organizacje oraz życie rodzinne i społeczne, „Master of Business Administration”, nr 1(116).

Saks A.M. (2006), Antecedents and Consequences of Employee Engagement, „, Journal of Managerial Psychology", vol. 21, nr 7, http://www.emeraldinsight.com/doi/full/ 10.1108/02683940610690169 (data dostępu: 4.04.2018).

\section{Employees Feeling Respect as a Chosen Predictor of Involvement in the Organisational}

(Abstract)

Current management of human capital is not limited to the motivation of workers to perform their duties. Companies strive to build capital with employees who are both motivated and involved in the organisation. A high level of commitment obviously brings organisations numerous benefits, and although the issue has been discussed for years, it remains a source of scientific interest and business. Involved employees are loyal to their companies beyond the scope of their duties, and act upon their own initiative, often contributing to improved organisational efficiency.

The article pays particular attention to the need for employees to feel respect from supervisors and its importance for affective, normative and lasting engagement.

Keywords: organisational commitment, experience of respect, relations with the supervisor, employee recognition. 